\title{
Facebook and Instagram Business Account Management under the Pandemic Influence
}

\author{
Alona Natorina* \\ Kyiv National University of Trade and Economics, Department of Trading Business and Logistics, \\ 02156, Kyiv, 19, Kyoto str., Ukraine
}

\begin{abstract}
The crucial role of maintaining business accounts on social media for the rational organization of goods promotion in the COVID-19 pandemic context and increasing online business awareness is reasonably justified. Based on empirical research and analysis of Ukrainian retailers' online stores, business account metrics are diagnostics in social media. The interpretation of the viral loop in social media is proposed, and the meaning of the definitions "subcritical mass" and "critical mass" of a Facebook / Instagram business account are clarified. The dynamic model of a critical mass of Facebook / Instagram business accounts is developed. The model allows monitoring the nature and influence of active followers on users to adjust the current vector of activity, minimize marketing costs, and increase the target audience involvement. The model also facilitates accurate targeting and error-free ad placement for online businesses. Keywords: social media, business accounts, online business, Facebook / Instagram business account, account management.
\end{abstract}

\section{Introduction}

In the context of the globalization of the business environment, characterized by the scale of digital transformations and intensive competition, social media have a significant impact on developing an effective strategy for online businesses as they guarantee their progressive economic development. In particular, over the past ten years, the most popular social media in Ukraine - Facebook (Fig. 1), even though since 2017 it has had a steady decline in its market share. For example, the most popular social media among Ukrainian Internet users during 2011-2021 were Facebook, Twitter, Pinterest, Instagram, YouTube, Reddit, and Tumbler. Twitter and Pinterest were in second and third places in popularity among Ukrainians.

It is worth noting the significant increase in the audience of Twitter, whose market share increased in 2021 by about two times compared to 2020, due to the introduction of new and user-friendly innovations. Facebook, Pinterest, and YouTube at the beginning of 2021 lost some of their Internet users compared to 2020. Thus, Facebook's market share at the beginning of 2021 was $61.29 \%$, which is $7.86 \%$ less than in 2020 and $24.85 \%$ more than in 2017 . This is due to the growing interest of Internet users of the social media Instagram.

* Corresponding author: a.natorina@,knute.edu.ua 
If in 2017 the market share of Instagram was $0.08 \%$, then by the beginning of 2021 , its value increased by $8.45 \%$. In 2021, compared to 2020 , the growth rate of Instagram's market was $287 \%$. In addition, it should be noted that taking into account the peculiarities of the content on Instagram, since 2019, YouTube began to lose a significant part of its audience, and its market share by the beginning of 2021 was, for the first time in 5 years, less than on Instagram and was $3,21 \%$.

Taking into account the above and interests of Internet users, online business should use the capabilities of popular social media to develop and promote their business effectively.

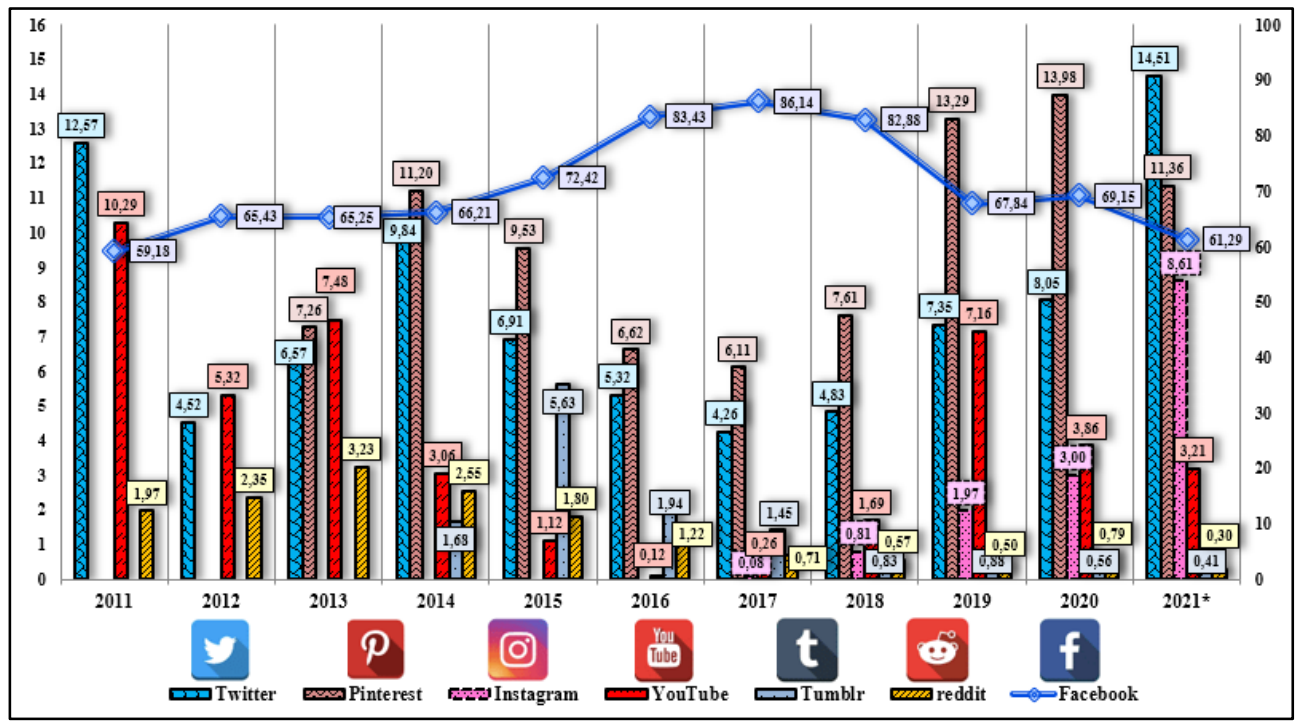

Notes. * - January-February, 2021

Fig. 1. Market shares of the most popular social media in Ukraine, \% (calculated and created by the author according to [1])

\section{Brief Literature Review}

The positive impact of social media on online business development with relevant communication strategy that is studied and interpreted in works [2-6]. The specifics of business accounts administration in social media are described in publications [7-10]. The main advertising content characteristics in social media and the role of an online platform for attracting the target audience are thoroughly reflected in articles and reports [11-16]. Despite the significant scientists' contribution and without diminishing the importance of scientific achievements, it should be stated; it is necessary to mention the fragmentation of the study of business account management in social media.

\section{Purpose}

The study aims to develop methodological tools and guides for an online business that allows monitoring the effectiveness of Facebook / Instagram business account management.

\section{Results}




\subsection{Empirical research background}

As part of empirical study and complex analysis of the online business of Ukrainian retailers [17-18], the systematicity of updating business accounts content of retailers' online stores in social media is determined. Additionally, it should be noted that all retailers were divided into three clusters:

Cluster 1: Auchan Ukraine (FR1), Metro Cash and Carry Ukraine (FR2), NOVUS Ukraine (FR4), Yves Rocher Ukraine (DR1), RUSH (DR2), ALLO (HA1), Foxtrot (HA2), DIESA (HA3), Comfy-Trade (HA4), Harazh Mobail Hrup (HA5), Citrus Discount (HA6), Leroy Merlin Ukraine (DIY5).

Cluster 2: NASH KRAI (FR3), Tavria V (FR5), Fozzy Food (FR6), Budmax (DIY3).

Cluster 3: BRV Kyiv (DIY1), Nova Linia (DIY2), Epicentr K (DIY4), Mebelna Kompaniia Ukrainy (DIY6), JYSK Ukraine (DIY7).

Table 1 represents business accounts of Ukrainian retailers' online stores in social media and the regularity of their content updating.

Table 1. Business accounts of Ukrainian retailers' online stores in social media and regularity of their content updating (built by the author based on research in social media, January 2021)

\begin{tabular}{|c|c|c|c|c|}
\hline Metrics & $\begin{array}{l}\text { Facebook } \\
\text { business } \\
\text { account }\end{array}$ & $\begin{array}{c}\text { Systematically } \\
\text { updated } \\
\text { content on } \\
\text { Facebook }\end{array}$ & $\begin{array}{c}\text { Instagram } \\
\text { business } \\
\text { account }\end{array}$ & $\begin{array}{l}\text { Systematically } \\
\text { updated } \\
\text { content on } \\
\text { Instagram }\end{array}$ \\
\hline Cluster 1 & $\begin{array}{l}\text { FR1, FR2, FR4, } \\
\text { DR1, DR2, HA1, } \\
\text { HA2, HA3, HA4, } \\
\text { HA5, HA6, DIY5 }\end{array}$ & $\begin{array}{l}\text { FR1, FR2, FR4, } \\
\text { DR1, DR2, HA1, } \\
\text { HA2, HA3, HA4, } \\
\text { HA5, HA6, DIY5 }\end{array}$ & $\begin{array}{l}\text { FR1, FR2, FR4, } \\
\text { DR1, DR2, HA1, } \\
\text { HA2, HA3, HA4, } \\
\text { HA5, HA6, DIY5 }\end{array}$ & $\begin{array}{l}\text { FR1, FR2, FR4, } \\
\text { DR1, DR2, HA1, } \\
\text { HA2, HA3, HA4, } \\
\text { HA5, HA6, DIY5 }\end{array}$ \\
\hline $\begin{array}{c}\% \text { of } \\
\text { retailers }\end{array}$ & 100 & 100 & 100 & 100 \\
\hline Cluster 2 & $\begin{array}{c}\text { FR3, FR5, FR6, } \\
\text { DIY3 }\end{array}$ & FR3, FR5, FR6 & FR3 & FR3 \\
\hline $\begin{array}{c}\% \text { of } \\
\text { retailers }\end{array}$ & 100 & 75 & 25 & 25 \\
\hline Cluster 3 & $\begin{array}{l}\text { DIY1, DIY2, } \\
\text { DIY4, DIY6, } \\
\text { DIY7 }\end{array}$ & $\begin{array}{l}\text { DIY2, DIY4, } \\
\text { DIY6, DIY7 }\end{array}$ & $\begin{array}{l}\text { DIY1, DIY2, } \\
\text { DIY4, DIY6, } \\
\text { DIY7 }\end{array}$ & $\begin{array}{l}\text { DIY2, DIY4, } \\
\text { DIY6, DIY7 }\end{array}$ \\
\hline $\begin{array}{c}\% \text { of } \\
\text { retailers }\end{array}$ & 100 & 80 & 100 & 80 \\
\hline
\end{tabular}

The data obtained during the empirical study (Table 1) show that the business accounts of Ukrainian retailers on Facebook and Instagram play a crucial role for most Ukrainian online retailers, in particular in building relationships with the target audience and increasing its level of loyalty. It is essential to mention that six retailers from the total quantity (FR1, FR2, FR4, FR3, FR6, DIY4) had Facebook and Instagram business accounts, which function separately from the online storefront.

\subsection{A dynamic model of a critical mass of Facebook / Instagram business account}

The author developed the dynamic model of critical mass of Facebook / Instagram business account to solve the above problem. The main advantage of this model is the systematic tracking of changes in the number of active followers and identification of the nature of their influence on social media users. Moreover, the proposed model is the foundation for making balanced management decisions for an online business to determine the current actions on 
the Internet. The critical mass of a Facebook / Instagram business account is an accelerator for an increase in the number of potential buyers and, consequently, a determinant of the multiplier effect from sales. The subcritical mass of a Facebook / Instagram business account is the number of followers, which is not enough to attract new followers and activate the viral loop. The minimum number of followers that form the subcritical mass depends on the specifics and scale of the business and is determined based on empirical research. Fig. 2 graphically interprets the subcritical (a) and critical (b) mass of a Facebook / Instagram business account.

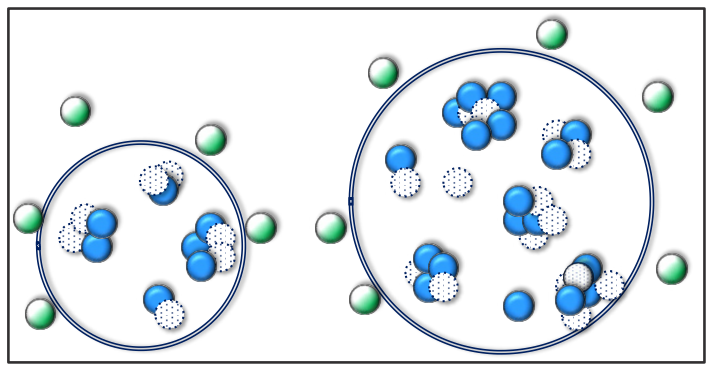

a)

b)
Notes:

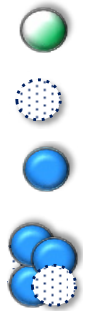

- Facebook / Instagram user

- new involved Facebook /

Instagram follower

- active Facebook / Instagram

follower

- collaboration of active and

new involved Facebook /

Instagram followers

Fig. 2. The subcritical (a) and critical (b) mass of a Facebook / Instagram business account (created by the author)

According to Fig. 2, the critical mass of a Facebook / Instagram business account depends on the interaction frequency, particularly of the active followers' communication with Facebook / Instagram users, who form the target audience. Therefore, with a low level of interaction between active followers of a business account and users who form the target audience on Facebook / Instagram, the rate of building up the critical mass - decreases. Thus, the guarantee of the rapid growth of the Facebook / Instagram business account critical mass is an increasing number of active followers to accelerate the passage of Facebook / Instagram users through the three stages of becoming an active follower and expanding the target audience, as well as encouraging it to make purchases in the online store.

Considering the above, online businesses should aim to intensively increase the number of active followers of the Facebook / Instagram business account by planning, developing, and implementing relevant marketing campaigns, considering the type and the target audience characteristics. In addition to traditional means of the target audience segmenting in social media, online businesses should use a parser. This program/script provides a particular mathematical model for its development and allows to scan, compare, and clearly identify the target audience preferences.

Nevertheless, in practice, it is impossible to accurately predict the time to reach the desired critical mass on the Internet, the speed and rate of its growth. However, systematic tracking of changes in the critical mass of a Facebook / Instagram business account will identify specific trends and make an informed online business management decision in the framework of following the general goal and implementing short-term and long-term measures. Based on this, the dynamic model of a critical mass of Facebook / Instagram business account was developed (1) in order to monitor and conduct a retrospective analysis of the total number of Facebook / Instagram business account followers, as well as to identify changes in the subcritical mass and the effectiveness of the influence of active followers on the conversion from Facebook / Instagram users to new followers. This will correct if it is necessary for online business, choose a vector of activities, and implement a plan to increase the critical mass of a Facebook / Instagram business account in perspective.

$$
M_{c r}=M_{s u b}+F_{n}-F_{u n},
$$


Where $M_{c r}$ - critical mass; $M_{\text {sub }}$ - number of followers that form a subcritical mass; $F_{n}-$ number of new involved followers; $F_{u n}$ - number of unsubscribed followers. So, $F_{u n}$ can be identified as the loss of online business share of the target audience in Facebook / Instagram because of a new competitor and the transition of followers to it.

According to (1), when $F_{n}>F_{u n}$, then $M_{c r}$ increases, and $M_{c r} \rightarrow \infty$. Otherwise, when $F_{n}<F_{u n}$, then $M_{c r}$ decreases and $M_{c r} \rightarrow 0$. With a sharp decrease in the number of followers, it is possible a situation when $F_{n}=F_{u n}=0$, a $M_{c r}=M_{s u b}$.

It is important to emphasize that $F_{n}$ reflects the cumulative amount of new Facebook / Instagram business account followers, attracted by active followers and those Facebook / Instagram users who became new business account followers, thanks to the successful marketing policy implementation (2):

$$
F_{n}=F_{\text {inv }}+F_{\text {ind }},
$$

Where $F_{\text {ind }}$ - number of users who became new followers without the influence of active followers on them (in the absence of interaction with active followers); $F_{\text {inv }}$ - number of new followers attracted by active followers. Thus, the dynamic model of a critical mass of Facebook / Instagram business accounts is (3):

$$
M_{c r}=M_{\text {sub }}+F_{\text {ind }}+F_{\text {inv }}-F_{\text {un }}
$$

The average number of new followers attracted by an active Facebook / Instagram follower of a business account $\left(F_{\text {inv_av }}\right)(4)$ :

$$
F_{\text {inv_av }}=\frac{F_{i n v}}{F_{a}},
$$

Where $F_{a}$ - number of active Facebook / Instagram business account followers.

According to (4), online businesses should strive to achieve the maximum average number of new attracted followers Finv_av=Finv/Fa under Finv $\rightarrow$ max and $\mathrm{Fa} \rightarrow$ min conditions. At the same time, the time $t$, which spends an active follower on communication with a Facebook / Instagram user to turn him into a new follower, plays a significant role in achieving Finv_max. Therefore, $F_{\text {inv } a v} \rightarrow \max , F_{\text {inv }} \rightarrow \max , F_{a} \rightarrow \min , t \rightarrow \min$. The visualization of the dependence of $M_{c r}$ on $t$ and $F_{a}$ in the dynamic model of a critical mass of a Facebook / Instagram business account is represented in Fig. 3.

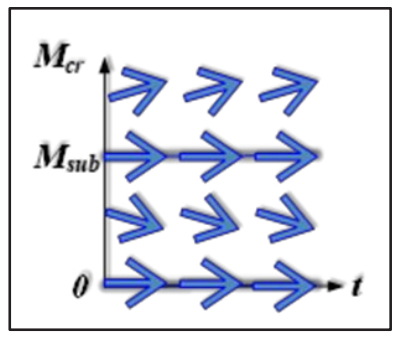

a)

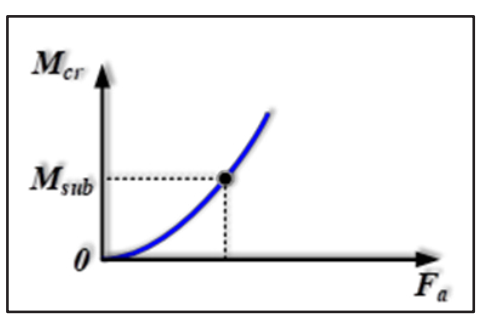

b)

Fig. 3. Dependence of Mcr on $\mathrm{t}(\mathrm{a})$ and Fa (b) (developed by the author)

According to Fig. 2, if $M_{c r}=0$, then the solution of the model is stable, while $M_{c r}=M_{s}-$ unstable. The last one is due to the inability to predict Fn and Fun accurately. With $M_{c r}=M_{s u b}$, one can observe both an increase and a decrease in the number of followers, which depends 
on the online business marketing policy and the chosen vector of activity. When Mcr $>$ Msub indicates a continuous increase in $\mathrm{Fa}$, and $M_{c r}<M_{s u b}-$ a constant decrease in $F_{a}$.

\section{Conclusion}

Using the developed dynamic model of a critical mass of a Facebook / Instagram business account in practice will make it possible to systematically track changes in the number of followers and show the nature and influence level of active followers on Facebook / Instagram users. Also, this model will serve as the basis for making informed management decisions to change the vector of online business activity in social media to reduce the cost of further marketing activities implementation.

\section{References}

1. Statcounter GlobalStats (2021), URL: https://gs.statcounter.com/

2. G. Appel, L. Grewal, R. Hadi, A. Stephen, Journal of the Academy of Marketing Science, 48, 79-95 (2019), URL:

https://link.springer.com/content/pdf/10.1007\%2Fs11747-019-00695-1.pdf

3. Capgemin (2021), URL: https://www.capgemini.com/

4. CISCO (2021), URL: https://www.cisco.com/c/uk_ua/index.html

5. J. Plantin, C. Lagoze, P. Edwards, C., New Media \& Society, 20 (1), 293-310 (2018)

6. S. Yermak, O. Bavyko, O. Boiko, N. Vasiutkina, Journal of Hygienic Engineering and Design, 27, 15-21. (2019), URL:

http://www.jhed.mk/filemanager/JHED\%20Vol.\%2027/01.\%20Full\%20paper\%20\%20Svitlana\%20Yermak.pdf

7. CIO (2021), URL: https://www.cio.com/

8. H. B. Dondolo, Problems and perspectives in management, 15 (2), 404-410. (2017)

9. R. G. Duffett, Young Consumers, 18 (1), 19-39 (2016), DOI: https://doi.org/10.1108/YC-07-2016-0062

10. M. Bondarchuk, O. Bavyko, Modern science - Moderni věda, 3, 5-13 (2019)

11. Content Strategy Alliance, Content strategy alliance tools and templates. A best practices handbook (2015), URL: http://contentstrategyalliance.com/wpcontent/uploads/2015/08/CSA-Handbook.pdf

12. EVO.business (2021), URL: https://evo.company/ua/

13. Isobar Ukraine (2021), URL: https://isobar.com.ua/

14. D. Lee, K. Hosanagar, H. Nair, Management Science, 64 (11), 1-41. (2018), DOI: http://dx.doi.org/10.1287/mnsc.2017.2902

15. Nielsen (2021), URL: http://www.nielsen.com/

16. H. Virtanen, P. Bjork, E. Sjostrom, Journal of Small Business and Enterprise Development, 24 (3), 468-484. (2017), DOI: https://doi.org/10.1108/JSBED-12-2016$\underline{0202}$

17. A. Natorina, Baltic Journal of Economic Studies, 5 (1), 131-136, DOI: https://doi.org/10.30525/2256-0742/2019-5-1-131-136 URL: http://www.baltijapublishing.lv/index.php/issue/article/view/610

18. A. Natorina, Economic Annals-XXI, 174 (11-12), 69-72 (2018), DOI: https://doi.org/10.21003/ea.V174-11 